\title{
Sensing a 'second coming': An overview of new concepts in Sociology, Philosophy, Law and Theology on the re-emerging religious in private and public life
}

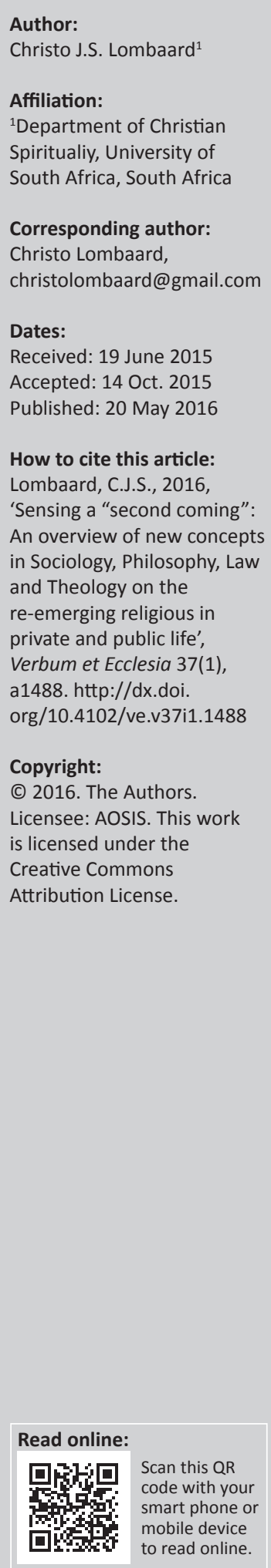

In a number of academic disciplines, expression has been given to the recently rising awareness that the category of the religious has not disappeared from public life. What the 'masters of suspicion' - Feuerbach, Marx, Nietzsche, Weber, Durkheim and Freud - had sensed was the intellectual spirit of their times and not the dawning of a broadly post-religious phase in Western/ised humanity. In different academic disciplines, this new awareness has been given expression to by means of a series of newly developed concepts. In this contribution, these developments are briefly tracked as they relate to one another. Although these formulations and discussions in some ways correspond to one another, it has not yet been undertaken to relate them to one another, which is the contribution of this article: these developments reflect, as largely parallel expressions, the recently rising awareness that the category of the religious is currently present in private and public life more so than in previous decades.

Intradisciplinary and/or interdisciplinary implications: This article traces recent developments in Sociology, Philosophy, Law and Theology on the unfolding place of religion in the world currently, as a first step to bringing these disciplines into discussion with one another on this matter.

\section{A future without God is as impossible as to be born without parents. (Waaijman 2015:n.p.) ${ }^{1}$}

\section{Out of mind, out of sight: God's disappearing trick}

God has always been gone - in this sense: no matter how real the experience of the divine had been for (religious) people throughout the ages, the holy presence has also always been strongly characterised by the holy absence. 'The mystery of the Praesentia Dei and the Deus Absconditus is [however not] to be understood as irreconcilable opposites' (Lombaard 2015a:95). In the JudeaChristian faith tradition and, hence for the greatest part, the Western/ised religio-cultural heritage, even directly revelatory moments remain just that: moments. This is as valid in the textual legacy of the Hebrew Bible (with the Moses and Isaiah revelations as some high points) as it is in the New Testament (with the Jesus and Paul revelations as some high points) and for mystics' encounters with God in subsequent history (cf. e.g. Krüger 2006; McGinn 1994). The most stable legacy we have from these revelatory moments are texts; although I disagree in some respects (cf. Budriunaite 2013:39-62; Lombaard 2015e:1) with Cupitt (1988:61, cf. pp. 8-9, 23-25, 35-36, 100), he is at this specific point correct: for us, mysticism is always written.

This 'God is not-t/here-yet-t/here' (Lombaard 2015a:92), Praesentia Dei - Deus Absconditus, tension, inherent in any religion that is reliant on a revelatory aspect (cf. Berkhof 2007:43-115), has found its expression in Western history too, in a broadly parallel way: the God who had always been just there, indubitably so, departed from everyday life in the modern era. Perhaps this may be called 'God's disappearing trick'. In his influential A Secular Age, Taylor (2007 - cf. van der Merwe 2015:4-5 for a recent summary; in different modes, see Boersma 2011; Goosen 2007) traces how the social conditions of pre-modernism and modernism or post-modernism pushed to the fore what could be described as the public default position regarding matters religious: a 'Big Yes' and a 'Big No', respectively (Lombaard 2015b:4).

\footnotetext{
1.This utterance by Waaijman should not be understood in any triumphalist sense. It is meant as an analytical expression (here predictive in nature), thus in full keeping with Waaijman's phenomenological approach to researching spirituality, most clearly evident in his 2000 published magnum opus, Spiritualiteit: Vormen, grondslagen, patronen, and its various translations.
}

Note: 'Religious innovation and religious change in the 21st century', paper presented at the Centre for Studies on New Religions conference, International Society for the Study of New Religions, Estonian Institute of Humanities, Tallinn University, Estonia, South Africa, 17-20 June 2015. 
The era of the two movements closer to us, the 'Big No' period since the birth of modernism, had been characterised by influential analysts of the human condition proposing the end of religious adherence, namely, as an expression of a more mature humanity. These figures are instantly recognisable as counting among the founders of our modern intellectual tradition: Feuerbach, Marx, Nietzsche, Weber, Durkheim and Freud - to whom have variously been attached the nomenclature of 'masters of suspicion' (Ricoeur 1970:32 on Marx, Nietzsche and Freud) and practitioners of the 'hermeneutics of suspicion' (so again, recently, Perrin 2013:335). Without these intellectual giants, the Western/ised world would have been immensely poorer in its critical, also self-analytical, activities of the mind. Naturally, our understanding of our money and power play, our psyches and bodies, amongst other matters, has developed further since these 19th- to 20th-century masters put forth their creative ideas. Yet, at the very least, the contributions of these intellectual figures can be characterised in the same way as those of one of the most influential theologians of the previous century, Gerhard von Rad (cf. especially 1957, 1960), as 'fruchtbare Mißverständnisse' (Smend 1989:226). Often, their original ideas remain foundational, their writings often becoming the verba vitae to which to return for currently influential academics and public intellectuals.

One of the most enduring legacies of these intellectual giants has been their shared idea that, within their foreseeable future, the practice of religion would fade away, to extinction. Religion would become a phenomenon of human history. This thought climate has led to the acceptance in circles of leadership and intelligentsia in the Western/ised world of what may be termed a public atheism or agnosticism, although certainly this often applied to the personal sphere as well. On the political stage, this intellectual atmosphere had already found its most influential expression in the French constitution ${ }^{2}$ and in the First Amendment to the US constitution, ${ }^{3}$ reflecting the various understandings of the separation of church and state, and in the USSR's formal antireligionism (cf. Pfaff 2012). In all these cases, the social situations to which they reacted by rejecting them had been done for (still) legitimate reasons; the solutions seem, however, not to have been fully culturally cogent. Hence, the social impulses from these three major sources of political influence of the previous century never resulted in a public sphere wholly free from religion, with aspects of faith always visible within society. Yet the oft-used terms of religion being sidelined and marginalised, and similar expressions (cf. e.g. Carson 2008:115-144), are accurate in this regard: the 20th century had, numerically and proportionally, been the most godless of all centuries. This 'silent night' did not happen because it was a 'holy night'.

2. The first article of the current constitution, namely of the Fifth French Republic Assemblee Nationale (1958), reads, 'La France est une République indivisible, laïque, démocratique et sociale. Elle assure l'égalité devant la loi de tous les citoyen sans distinction d'origine, de race ou de religion. Elle respecte toutes les croyances' (see http://www.assemblee-nationale.fr/connaissance/constitution.asp).

3. The First Amendment to the US constitution Cornell University Law School (1791) reads, 'Congress shall make no law respecting an establishment of religion, or prohibiting the free exercise thereof; or abridging the freedom of speech, or of the press; or the right of the people peaceably to assemble, and to petition the Government for redress of grievances' (see http://www.law.cornell.edu/constitution/first_amendment).
In a way, then, the predictions of these 'fathers of atheism' had become self-fulfilling prophecies, albeit for the most part in elite circles, and then not in all respects equally, with personal, social, regional, national and religious differences that may be traced as markers of diversity in this respect. For the elite ${ }^{4}$ during the 'silent night century', God may have been publically dead, but not in the same way for all and not equally so for all. In the societies that flowed from these thought impulses, the complexities and diversities resulted in a dichotomous situation in which the ideological commitments of the elite led to a kind of cap of invisibility. In this case, the cap of invisibility had the opposite effect to what it had been ascribed in ancient Greek mythology: it was not that the thinkers were invisible, but some aspect of their societies became invisible to them - God would become out of mind, out of sight.

\section{Come again?}

Naturally, the spirit of human enquiry in the Western intellectual tradition does not bear such (partial) blindness lightly. The first to sense this lacuna was the discipline of Sociology, followed by - in no particular order - Philosophy, Law and Theology.5 Some important aspects of these developments will now be indicated, with a focus on a few prominent individuals, and with a convergence of sensibilities becoming clear, albeit having developed quite distinct terminologies in the respective disciplines. This overview is offered with the hope that underpins the central contribution this essay seeks to make: to facilitate greater awareness and possibly discussion across disciplinary boundaries, as emerging aspects of religiosity in our time unfold in manifold ways.

\section{God rides again, sociologically}

Perhaps the most telling example in the discipline of Sociology of the change from scepticism to rekindled interest in religion as an important social reality is the work of Peter Berger. In a series of works (e.g. Berger 1967, 1969, 1979, 1981, $1999,2011)$, he moves on from the earlier classic theories of secularisation to the acceptance that impulses of faith 6 continue to play a major role in economic, political and other aspects of society. Wilson (1969:425; cf. Hammond 1969: 15-424) summarises this change as follows:

In The Sacred Canopy Peter Berger effects a rehabilitation of the sociological study of religion in the classical tradition of Weber and Durkheim, for a basic concern of Berger's work is what symbolic universe modern man is using to legitimate his society. This, in Berger's mind, is a fundamental question for the sociology of religion and of knowledge - indeed for all of sociological theory. The analysis of religion is not to be considered a marginal speciality of little interest to sociological theory but has essential contributions to make to it. (p. 425)

4.This includes, for the greatest part, the intelligentsia, who had studied at university and there had become influenced by the ideas of these intellectual greats - as naturally should be the case. The educated classes went on to fill the positions of leadership and influence - as is, except under extreme circumstances such as war or revolution, the case sociologically in most societies.

5. In the academic disciplines of Musicology and Medicine, a new orientation towards spirituality has played out in a different way, which will be tracked in research subsequent to this.

6. By 'impulses of faith' is meant here simply the sociological influence of religion. 
Based on a sociology of knowledge (cf. Berger \& Luckman 1966), which in some ways parallels the influential work of Kuhn (1962; cf. Küng \& Tracy 1989) on paradigms of scientific understanding, it was possible for Berger to turn this intellectual corner, and to do so influentially (cf. Woodhead, Heelas \& Martin 2001), on the basis of quantitative and qualitative sociological studies. He was by no means a lone figure, with colleagues such as Luckmann (e.g. 1991:167-182) and Casanova (e.g. 2012:27-46) as part of the trend in Sociology to take matters of religion seriously as an object of study, as Weber had done classically (cf. Otto 2005a \& Otto 2005b). The influence of this reawakening can also be seen in these two ways:

- The extension of the influential concept of social capital now also to refer to spiritual capital, a concept from Bourdieu (1986:241-258; cf. e.g. O'Sullivan \& Flanagan 2012), which may be understood as follows (Lombaard 2015d):

[T]he (often unreflected) translation of a person's or persons' highest sensibilities of faith and deepest sensitivities of faith into expressions of action and inaction.

These 'highest sensibilities' may refer to the divine or to creedal expressions (including negation - either as disavowal of the divine or as theology in the minor via negativa or mystic tradition) on the divine or to the noblest principles, religious or not.

The 'deepest sensitivities' indicates the (often unreflectedupon reflex) experience of the former.

Such experience is always transformational in the sense that it gives existential meaning and personal or social depth (cf. Baker 2012:14-19), referring both to emotive-psychological senses of (well) being and to actions taken or declined. (p. 7)

- The recent appearance of titles such as The Sociology of Spirituality (Flanagan \& Jupp 2007) and A Sociology of Prayer (Giordan \& Woodhead 2015), which under the previous, a-religious regime of Sociology would hardly have been possible.

As far as the discipline of Sociology is concerned, then, it in various ways no longer shows the aversion typical of modernism to matters of faith. In coming to more valid, grounded understandings of aspects of society, we can now get along on less of a wing and a prayer.

\section{For God's sake, philosophically}

The most influential initial philosophical text acknowledging the return of the religious to the public sphere is by Jürgen Habermas (2008:17-29), titled 'Secularism's Crisis of Faith: Notes on Post-Secular Society'. Both his grounding within the Frankfurter Schule, giving his philosophy a decidedly socio-analytical slant, and his fame as philosopher (see especially Habermas 1981a, 1981b) contributed to the success of this essay; the fact that he had himself followed a path similar to that sketched above of Berger with respect to the role and future of religion within society (cf. e.g. Habermas 2005) makes this philosophical-diagnostic contribution all the more telling. In a simple, brief manner, Habermas
(2008:17-29) analyses secularisation theory and offers reasons for its demise (Habermas 2008):

Above all, three overlapping phenomena converge to create the impression of a worldwide 'resurgence of religion': the missionary expansion; a fundamentalist radicalization; and the political instrumentalization of the potential for violence innate in many of the world religions. ${ }^{7}$ (p. 18)

In the process, Habermas popularises the term post-secularism, a concept that through various discussions (e.g. Casanova 2012:27-46) has been refined now to refer to the following (Lombaard 2015a):

Whereas in pre-modern society God was everywhere and in modern/post-modern society God was (almost) nowhere, both seem at the same time to be sound within a post-secular society. On personal, experiential scale, the expression 'turn to spirituality' characterises helpfully, despite objections, increased interest in new or ancient or alternative religions and, within established Christianity, in the quest for more experiential and mystic dimensions to faith. On a broader scale, communities are making sense of different incarnations of the Divine with which they are faced ... This 'everywhereness' of the religious is not experienced as divine omnipresence; though its sources lie far and wide, it is encountered locally and most often unreflectively. Still - the age old problem of finding God, solved in various Christian traditions by theological emphases on respectively the church, or liturgy, or the sacraments, or the Scriptures, or the Holy Spirit, or liberation, or nature - the Divine remains concealed, and even if perhaps found concretely through experience or conversion or revelation or reason, remains ineffable. (pp. 87-88)

In a recent philosophical contribution, Vanhoutte (2015a, cf. also 2015b:125-143) analyses what he calls 'theological turns' in contemporary continental philosophy. This he traces in trends in French phenomenology (with reference to e.g. Benson \& Wirzba 2010), in an extended section on a renewed interest in the apostle Paul from a philosophical perspective (with reference to e.g. Caputo \& Alcoff 2009), and within a group of philosophers who employ concepts from theological discourse (e.g. with reference to Agamben 2015). These concepts, however, need not be traditional theisms, as the work of Kearney (2001, 2010; cf. Manoussakis 2006) demonstrates: thinking of, living with, or believing anatheistically, that is, unknowingly, in a God beyond the possible, beyond metaphysics (Venter 2012:200-201; cf. Van der Merwe 2015:5-7 for a recent summary). ${ }^{9}$ This includes the idea that the holy is sensed in the daily, for which Bailey (1997, i.a.) had earlier devised the concept of 'implicit

\footnotetext{
7. The last two points are not to be misunderstood as scare tactics on the part of Habermas, in order either to lament or to encourage the return of religion to a position of importance in public, including political, life. Habermas simply reads the signs of the times: the events that have transpired and that he takes as indications that religion can no longer be ignored as a matter worthy of serious public consideration, as had in preceding generations become the norm in public life.

8. Kearney (2010:3) himself defines anatheism, thus not atheism along with not a theism, as 'a third way beyond the extremes of dogmatic theism and militant atheism ... [a] wager of faith beyond faith ... God after God ... another way of seeking and sounding the things we consider sacred but can never fully fathom or prove ... receiving back what we've given up as if we were encountering it for the first time ...
another way of returning to a God beyond and beneath the God we thought we possessed'.

9. In this regard may also be mentioned two 1991 books by the French phenomenologists Marion (1991) (God Without Being) and Lacoste (La phénoménalité de Dieu).
} 
religion ${ }^{\prime 10}$ - that at times, in unexpected ways, references to the divine find expression in common culture and individual acts. In a more abstract philosophical mode, the works by Benedikter (2005) and Bhaskar (2002) on neo-essentialism and critical realism offer alternatives for spirituality: no longer restricted by the uncertainties of postmodernism but partaking in a communally shared sense of what is, new avenues for thinking, living and believing beyond the death or the non-existence of God are opened (cf. Schreiber 2012:2, 2013).

Although a completely philosophical God could never provide much solace for a Christian sense of the divine, or mystique, the alternative is no alternative: God talk without philosophy cannot provide much grounding to thought and experience. It seems that the beginning of the new millennium offers more than just questioning, which characterised much of the previous two centuries' philosophy on religion. Roads recently less travelled may be built in Philosophy here.

\section{The Law of God}

Given the importance of legal statutes in ordering societies, sociological changes and philosophical moves within society tend to have greater effect when they take hold in legislation too. This had certainly proven to be the case with the moves towards secularisation, indicated above. Interestingly, these changes in constitutions and laws have traditionally been characterised as liberal, in the sense that they were understood to be integral to developing democracies in seeking to expand the individual freedoms (liberties) of the citizenry. This quest for freedom of the individual seemed in some historical cases to coincide well with what has become the cliché that 'freedom of religion' translated into 'freedom from religion'. This translates now into the additional realisation that freedom from religious coercion includes freedom from socially and legally enforced exclusion of matters relating to religion.

The negative expectation of religion, that it inhibits freedom which had, in some instances, no doubt been the case prior to democracy - was and is often still a popular expectation. ${ }^{11}$ However, in somewhat popular (Watson 2015) as much as in academic circles - with Benson (e.g. 2010, 2012, 2013a, 2013b:12-29) as a prime influence in this regard - the view of liberty as the exclusion of religion from public life is increasingly being questioned. This is because freedom of religion had oftentimes come to be understood in law as 'another meaning of "secular"[:] "mandating established unbelief" rather than simply opposing "established belief"' (Ahdar 2003:623, quoting the British Columbia Court of

10.Implicit religion refers to expressions of religious orientation without it being popularly realised that this is the case. The Weberian theory that capitalism springs from Calvinism would be a broad illustration; on another level, that female hospital Catholic nuns caring for the sick, would be another illustration.

11.In the West, this often includes a perceived opposition between human rights and the Bible; although this certainly seems to be the case from some public pronouncements from within Christian circles, it was historically not the case (cf. Lombaard 2011:74-93, drawing on, e.g. Otto 2002, 2004:181-188; Van de Ven, Dreyer \& Pieterse 2004; see also Engler 2000:339-365).
Appeal). This, then, sees the law, and with it the instruments of governance, not taking a distanced stance with respect to matters of faith but rather (Lombaard 2016):

[retaining] a very special relationship to religion, namely that [the state] assumed unto itself the power of exclusion. In such a kind of exclusive liberalism, a liberal (that is: seeking expressions of freedom for its citizens, in all respects possible) state restricts any matter of religious orientation from its ambits. Governance should be God-free. This interpretation of a liberal democratic dispensation however has in fact not shed the earlier, feudal connection between God and king. It has merely inversed the social order: whereas the state would until the late 18th century reflexively involve the church (in one of its preferred forms) in as many matters of governance as possible, now the opposite would be administered by the state: religion would purposively be excluded from the same. This constituted no true break in the tradition of church-state relations. (p. 4)

As alternative, Benson (e.g. 2008:297-312, 2010, drawing on i.a. Gray 2000) speaks of an inclusive liberalism or liberalism unbound or pluralistic liberalism, ${ }^{12}$ in which pluralism, and also religious heterogeneity, is worked out in society to as full an extent as the diversities require, without one value, such as the religion-free option, being made dominant over others by legal or political means. Here - to adapt just a little the Kris Kristofferson/Fred Foster lyrics of the song 'Me and Bobby McGee' - freedom is not just another word for nothing left to lose; rather, liberty leaves open as many options to choose from as are called for in as open a society as possible.

This kind of legal and political framework sets the scene for a normalised position of religion, in which faith matters are neither privileged (pre-modernism) nor disadvantaged (modernism) by mere virtue of being a particular phenomenon, namely religion.

\section{One go(o)d turn ... spiritually}

In theological academia, two prominent publications had pointed out what has become known as the turn to spirituality:

- Ashley, M., 1995, 'The turn to spirituality? The relationship between theology and spirituality', Christian Spirituality Bulletin 3(2), 13-18.

- Kourie, C., 2006, "The "turn" to spirituality', in P. de Villiers, C. Kourie, \& C. Lombaard (eds.), The spirit that moves: Orientation and issues in spirituality, pp. 19-38 (Acta Theologica Supplementum 8), University of the Free State Press, Bloemfontein.

These publications are not based on empirical work but rather on a sensitivity towards current changes in publicly perceptible sentiment and in publications - as thoughtful, searching contributions often are. These two publications do not plead for anything new but for a recouping of what may be termed an undercurrent in Christianity across 20 centuries, namely of the mystical or the more spiritual experience of faith (cf. Kourie 1992:83-103), rather than the more cataphatic,

12.These three terms are synonymous expressions found across the writings of Benson, the shared intent of which are about to be described in the next lines. 
proclamational theology dominant throughout church history. Though this may at first seem to be an inward-looking expression of Christianity, it has decidedly interreligious tones too, with the term interspirituality (Kourie 2011:10-31) giving expression to this dimension shared between religiosities, ${ }^{13}$ although not in the older, essentialist sense that religions are inherently the same. Rather, the experience of the divine, borne from tradition and encounter, stands central to what is sought for here, along with the deep-going transformation this brings about in the individuals concerned and their societies ${ }^{14}$ (cf. Lombaard 2015c).

Many of the matters stated above can be brought into sharp question, as indeed Creaven (2010) has done in his Against the Spiritual Turn. Marxism, Realism and Critical Theory. To do so on materialist grounds is certainly healthy here at the dawning of writing on the experiential side of human spirituality, the inclusively liberal society, the (non) transcendental divine, and the continually searching society, all indicated above. However, this may perhaps be a case of modernist and post-secularist 'continental drift', as new ways of religiosity are sought for amidst what has been established (cf. Schrijvers 2011:31-35). Perhaps firmer footings are required within these newer developments to establish deeper critical reflection - as our intellectual heritage always wills.

\section{Unfolding future}

'I see no possibility of thinking of the future without God' (Waaijman 2015:n.p.).

Precisely how this prediction by Waaijman of Spirituality Studies (cf. Waaijman 2000) will turn out remains to be seen. What seems clear, though, is that in various disciplines (popular music, Musicology, Anthropology, Medicine, Communication Studies, the emerging discipline of Biblical Spirituality, Architecture, Art History, etc.) there are changes afoot that indicate new sensitivities. The changes are not without some convergence on the rekindled interest in and importance of religion, albeit not only in its older, more established forms. These are 'searching trends' that have been identified here, namely as not directly related, more or less parallel developments, in an attempt - this contribution - to bring them into greater discussion with one another. Perhaps Waaijman is correct, and one may speak with Rahner (1976:1518, i.a.) about 'the absolute future of God'; however, as these awarenesses are dawning, insecurely in individuals and in broader society and widely across many disciplines, let us do so softly, in humble mumble.

13. Interspirituality is thus related to interreligious and ecumenical contact but seeks to transcend the discursive, dialogical mode of many such interactions by deliberately making room for the experiential, which may in some ways be unique to each respective religious expression and in some ways related.

14.The latter is important because spirituality is at times misunderstood as relating only to the 'inward-looking' mentioned above. However, spirituality has as much to only to the ' cannot ou with the other, they mutually feed into cannot do with the other; they mutually feed into "ins experience and action, inner space and visible deeds, are at times only analytically distinguishable but are not generally acknowledged as such by the people concerned.

\section{Acknowledgements Competing interests}

The author declares that he has no financial or personal relationships that may have inappropriately influenced him in writing this article.

\section{References}

Agamben, G., 2015, Stasis. La guerra civile come paradigma politico, Bollati Boringhieri, Torino.

Ahdar, R., 2003, 'Indigenous spiritual concerns and the secular state: Some New Zealand developments', Oxford Journal of Legal Studies 23(4), 611-637.

Ashley, M., 1995, 'The turn to spirituality? The relationship between theology and spirituality', Christian Spirituality Bulletin 3(2), 13-18.

Assemblee Nationale, 1958, Constitution de la République française, viewed n.d., from http://www.assemblee-nationale.fr/connaissance/constitution.asp

Bailey, E., 1997, Implicit religion in contemporary society, Kok Pharos, Kampen.

Baker, C., 2012, 'Exploring spiritual capital: Resources for an uncertain future?', in M. O'Sullivan \& B. Flanagan (eds.), Spiritual capital: Spirituality in practice in Christian perspective, pp. 7-22, Ashgate, Farnham.

Benedikter, R., 2005, Postmodern spirituality. A dialogue in five parts. Part V: Can only a God save us? Postmodern proto-spirituality and the current global turn to religion, viewed n.d., from http://www.integralworld.net/benedikter5.html

Benson, B.E. \& Wirzba, N. (eds.), 2010, Words of life. New theological turns in French phenomenology, Fordham University Press, New York.

Benson, I.T., 2008, 'The case for religious inclusivism and the judicial recognition of religious associational rights: A response to Lenta'. Constitutional Court Review 1 , 297-312.

Benson, I.T., 2010, Living together with disagreement: Pluralism, the secular and the fair treatment of beliefs in Canada today (with a response by Alex Fielding), The Chester Ronning Centre for the Study of Religion and Public Life, Camrose, Chester
Alberta.

Benson, I.T., 2012, Living together with disagreement: Pluralism, the secular and the fair treatment of beliefs in law today, Connor Court Publishing, Ballan, Australia.

Benson, I.T., 2013a, 'An associational framework for the reconciliation of competing rights claims involving the freedom of religion', PhD dissertation, University of the Witwatersrand, Johannesburg.

Benson, I.T., 2013b, 'Seeing through the secular illusion', Nederduitse Gereformeerde Teologiese Tydskrif 54, 12-29.

Berger, P.L., 1967, The sacred canopy: Elements of a sociological theory of religion, Doubleday, Garden City.

Berger, P.L., 1969, A rumor of angels: Modern society and the rediscovery of the supernatural, Doubleday, Garden City.

Berger, P.L., 1979, The heretical imperative: Contemporary possibilities of religious affirmation, Anchor Press, Garden City.

Berger, P.L., 1981, The other side of God: A polarity in world religions, Anchor Press, Garden City.

Berger, P.L. (ed.), 1999, The desecularization of the world: Resurgent religion and world politics, Ethics and Public Policy Center, Washington, D.C.

Berger, P.L., 2011, Dialogue between religious traditions in an age of relativity, Mohr Siebeck, Tübingen.

Berger, P.L. \& Luckmann, T., 1966, The social construction of reality: A treatise in the sociology of knowledge, Doubleday, Garden City.

Berkhof, H., 2007, Christelijk geloof (negende, ongewijzigde druk), Uitgeverij Kok, Kampen.

Bhaskar, R., 2002, The philosophy of meta-reality, Sage, London.

Boersma, H., 2011, Heavenly participation: The weaving of a sacramental tapestry, William B Eerdmans, Grand Rapids, MI.

Bourdieu, P., 1986, 'The forms of capital', in J. E. Richardson (ed.), Handbook of theory and research for the sociology of education, pp. 241-258, Greenwood Press, New York.

Budriunaite, A., 2013, 'Investigation into mysticism: Limits and possibilities', in J.L. Hochheimer \& W. S. Schmidt (eds.), Spirituality in the 21st century: Explorations, pp. 39-62, Inter-Disciplinary Press, Oxford.

Caputo, J.D. \& Alcoff, L.M. (eds.), 2009, St. Paul among the philosophers, Indiana University Press, Bloomington, IN.

Carson, D.A., 2008, Christ and culture revisited, William B. Eerdmans, Grand Rapids, MI.

Casanova, J., 2012, 'Are we still secular? Explorations on the secular and the postsecular', in P. Nynäs, M. Lassander \& T. Utriainen (eds.), Post-secular society, pp. 27-46, Transaction Publishers, New Brunswick, NJ.

Cornell University Law School, 1791, Legal Information Institute, viewed n.d., from http://www.law.cornell.edu/constitution/first_amendment 
Creaven, S., 2010, Against the spiritual turn: Marxism, realism and critical theory, Routledge, Abingdon.

Cupitt, D., 1988, Mysticism after modernity, Blackwell, Oxford.

Engler, M., 2000, 'Toward the "rights of the poor": Human rights in liberation theology', The Journal of Religious Ethics 28(3), 339-365.

Flanagan, K. \& Jupp, P.C. (eds.), 2007, The sociology of spirituality, Ashgate, Aldershot. Giordan, G. \& Woodhead, L. (eds.), 2015, A sociology of prayer, Ashgate, Aldershot. Goosen, D., 2007, Die nihilisme, Notas oor ons tyd, Praag, Pretoria.

Gray, J., 2000, Two faces of liberalism, The New Press, New York.

Habermas, J.,1981a, Theorie des kommunikativen Handelns, Bd. 1: Handlungsrationalität und gesellschaftliche Rationalisierung, Suhrkamp Verlag, Frankfurt am Main.

Habermas, J., 1981b, Theorie des kommunikativen Handelns, Bd. 2: Zur Kritik der funktionalistischen Vernunft, Suhrkamp Verlag, Frankfurt am Main.

Habermas, J., 2005, Zwischen Naturalismus und Religion: Philosophische Aufsätze, Suhrkamp Verlag, Frankfurt am Main.

Habermas, J., 2008, 'Secularism's crisis of faith: Notes on post-secular society', New Perspectives Quarterly 25, 17-29.

Hammond, P.E., 1969, 'Peter Berger's sociology of religion: An appraisal', Sounding 52(4), 415-424.

Kearney, R., 2001, The God who may be: A hermeneutics of religion, Indiana University Press, Bloomington, IN.

Kearney, R., 2010, Anatheism: Returning to God after God, Columbia University Press, New York.

Krüger, K., 2006, Sounding unsound. Orientation into mysticism, Aurora Press, Pretoria.

Kourie, C., 1992, 'Mysticism: A survey of recent issues', Journal for the Study of Religion 5(2), 83-103.

Kourie, C., 2006, 'The "turn" to spirituality', in P. de Villiers, C. Kourie, \& C. Lombaard (eds.), The spirit that moves. Orientation and issues in spirituality (Acta Theologica, Supplementum 8), pp. 19-38, University of the Free State Press, Bloemfontein.

Kourie, C., 2011, 'Crossing boundaries: The way of interspirituality', Religion \& Theology 18(1\&2), 10-31.

Kuhn, T.S., 1962, The structure of scientific revolutions, University of Chicago Press, Chicago, IL.

Küng, H. \& Tracy, D. (eds.), 1989, Paradigm change in theology. A symposium for the future, T\&T Clark, Edinburgh.

Lacoste, J-Y., 1991, La phénoménalité de Dieu: Neuf etudes, Cerf, Paris.

Lombaard, C., 2011, Biblical spirituality and human rights, Old Testament Essays 24(1), 74-93.

Lombaard, C., 2015a, '"And never the twain shall meet"? Post-secularism as newly unfolding religio-cultural phase and wisdom as ancient Israelite phenomenon, spiritualities and implications compared and contrasted', Journal of Theology for Southern Africa 152, 82-95.

Lombaard, C., 2015b, 'A next TIER: Interdisciplinarity in theological identity/education/ research (TIER) in a post-secular age', paper presented at 'The Interplay between Theology and Other Disciplines in Research and in Theological Education conference, Faculty of Theology, University of Latvia, Riga, 14-16 April 2015, and the School of Social Sciences conference, Unisa, Pretoria, 02-03 September 2015.

Lombaard, C., 2015c, 'Biblical spirituality and transformation', In die Skriflig/In Luce Verbi 49(2), Art. \#1950, 6 pages. http://dx.doi.org/10.4102/ids.v49i2.1950

Lombaard, C., 2015d, 'Deus ex Machina? Religious texts, spiritual capital and inequalities: In continuation of a current debate (a response to colleague
Farisani)', Verbum et Ecclesia 36(1), Art. \#1378. http://dx.doi.org/10.4102/ Farisani)', Verbur
ve.v36i1.1378

Lombaard, C., 2015e, 'Mysticism and/in the Old Testament: Methodological orientation and a textual example', HTS Teologiese Studies/Theological Studies 71(1), Art. \#2813, 5 pages. http://dx.doi.org/10.4102/hts.v71i1.2813

Lombaard, C., 2016, 'Theological education, considered from South Africa: Current issues for cross-contextual comparison', HTS Teologiese Studies/Theological Studies 72(1), 5 pages. http://dx.doi.org/10.4102/hts.v72i1.2851

Luckmann, T., 1991, 'The new and the old in religion', in P. Bourdieu \& J. S. Coleman (eds.), Social theory for a changing society, pp. 167-182, Westview Press, Boulder, CO.

Manoussakis, J.P., 2006, After God. Richard Kearney and the religious turn in continental philosophy, Fordham University Press, New York.
Marion, J-L., 1991, God without being, University of Chicago Press, Chicago.

McGinn, B., 1994, The foundations of mysticism, vol. I: Of the presence of God, a history of Western Christian mysticism, Crossroad, New York.

O'Sullivan, M. \& Flanagan, B. (eds.), 2012, Spiritual capital: Spirituality in practice in Christian perspective, Farnham, Ashgate.

Otto, E., 2002, Gottes recht als Menschenrecht. Rechts- und literaturhistorische Studien zum Deuteronomium (Beihefte zur Zeitschrift für altorientalische und biblische Rechtsgeschichte, series 2), Harrassowitz Verlag, Wiesbaden.

Otto, E., 2004, “Wer wenig im Leben hat, soll viel im Recht haben": Die kulturhistorische Bedeutung der Hebräischen Bibel für eine moderne Sozialethik', kulturhistorische Bedeutung der Hebräischen Bibel für eine moderne Sozialethik',
in B. M. Levinson \& E. Otto (eds.). Recht und Ethik im Alten Testament (Altes in B. M. Levinson \& E. Otto (eds.), Recht und Ethik im Alten
Testament und Moderne 13), pp. 181-188, LIT Verlag, Münster.

Otto, E. (eds.) 2005a, Weber, Max: Die Wirtschaftsethik der Weltreligionen. Das Antike Judentum. Schriften und Reden 1911-1920 (Max Weber-Gesamtausgabe, Band I/21,1), Vol. 1, Mohr Siebeck, Tübingen.

Otto, E. (eds.) 2005b, Weber, Max: Die Wirtschaftsethik der Weltreligionen. Das Antike Judentum. Schriften und Reden 1911-1920 (Max Weber-Gesamtausgabe, Band I/21,1), Vol. 2, Mohr Siebeck, Tübingen.

Perrin, D.B., 2013, 'Hermeneutical methodology in Christian spirituality', Theoforum $44,317-337$

Pfaff, S., 2012, 'Religion under communism: State regulation, atheist competition, and the dynamics of supply and demand', in R.M. McCleary (ed.), The Oxford handbook of the economics of religion (Oxford Handbooks Online), Oxford University Press, Oxford. http://dx.doi.org/10.1093/oxfordhb/9780195390049. 013.0012

Rahner, K., 1976, 'Salvation', in K. Rahner (eds.), Encyclopedia of theology: A concise sacramentum mundi, pp. 1517-1518, Burns \& Oates, New York.

Ricoeur, P., 1970, Freud and philosophy. An essay on interpretation, Yale University Press, New Haven, CT.

Schreiber, D.A., 2012, 'On the epistemology of postmodern spirituality', Verbum et Ecclesia 33(1), 1-8.

Schreiber, D.A., 2013, 'Joined-up knowledge for a joined-up world: Critical realism, philosophy of meta-reality and the emancipation in/of anthropological spirituality: An exploration of confluences', MTh dissertation, University of South Africa, Pretoria.

Schrijvers, J., 2011, Ontotheological turnings? The decentering of the modern subject in recent French phenomenology, State University of New York Press, New York.

Smend, R., 1989, Deutsche Alttestamentler in drei Jahrhunderten, Vandenhoeck \& Ruprecht, Göttingen.

Taylor, C., 2007, A secular age, Harvard University Press, Cambridge, MA.

Van der Merwe, D., 2015, 'Rethinking biblical hermeneutics for mobilizing Christian believers to proclaim the good news in a post-secular age', Missionalia 43(2), 166-185.

Van der Ven, H.A., Dreyer, J.S. \& Pieterse, H.J.C., 2004, Is there a God of human rights? The complex relationship between human rights and religion: A South African case, Brill, Leiden.

Vanhoutte, K., 2015a, 'And the word turned once more to the flesh. Or on the various "theological turns" in contemporary continental philosophy', paper presented at "The Interplay between Theology and Other Disciplines in Research and in Theological Education" conference, Faculty of Theology, University of Latvia, Riga, 14-16 April 2015.

Vanhoutte, K., 2015b, 'Chi ha paura della filosofia contemporanea continentale? Per una prospettiva di dialogo con il francescanesimo', Antonianum XC(1), 125-143.

Venter, R., 2012, 'Thinking about God today: Eavesdropping on four discourses', Nederduitse Gereformeerde Teologiese Tydskrif 53, 195-204.

Von Rad, G., 1957, Theologie des Alten Testaments, Band 1: Die Theologie der geschichtlichen Überlieferung Israels, Chr. Kaiser Verlag, München.

Von Rad, G., 1960, Theologie des Alten Testaments, Band 2: Die Theologie der prophetischen Überlieferung Israels, Chr. Kaiser Verlag, München.

Waaijman, K., 2000, Spiritualiteit: Vormen, grondslagen, patronen, Carmelitana, Ghent.

Waaijman, K., 2015, 'Spirituality in the 21st century', paper presented at the 'Holiness: On the Holy, the Holy One, Sanctification and Saints' conference, Saint Augustine College, Johannesburg, South Africa, 20-23 May 2015.

Watson, B., 2015, 'Can we move beyond the secular state?', Religions 6(4), 1457-1470.

Wilson, J., 1969, 'The de-alienation of Peter Berger', Soundings 52(4), 425-433.

Woodhead, L., Heelas, P. \& Martin, D. (eds.), 2001, Peter Berger and the study of religion, Routledge, Abingdon. 